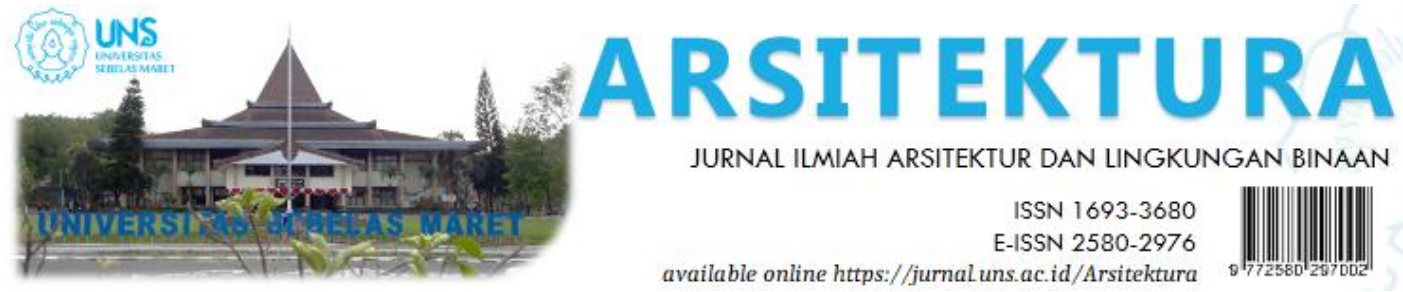

Volume 17 Issue 2 October 2019, pages:249-260

\title{
Efektifitas Metode Eksplorasi Konsep dalam Studio Perancangan Arsitektur Tematik Bagi Mahasiswa Studi Kasus: Universitas Merdeka Surabaya
}

\section{Effectiveness of Concept Exploration Methods in Thematic Architectural Design Studio for Student Case Study: Universitas Merdeka Surabaya}

\author{
Vijar Galax Putra Jagat Paryoko ${ }^{1 *}$ \\ Program Studi Arsitektur, Fakultas Teknik, Universitas Merdeka Surabaya ${ }^{1 *}$ \\ Email : vijargalax@gmail.com*
}

DOI: https://doi.org/10.20961/arst.v17i2.33154

Received:July 31, 2019 Revised: October 1, 2019 Accepted: October 1, 2019 Available online:October 31, 2019

\begin{abstract}
Study in thematic architectural design studios for undergraduate students requires the participants to be able to convey the image and the meaning behind it through architectural design. Skills on comprehensive design process and utilization of appropriate methods are determine the success on implementing architectural meanings through design theme. This research aims to find exploring ideas methods which are effective be used to for generate thematic concepts. The research uses qualitative strategies to examine the processes and products outcomes of studio participant's study that are controlled through design theories which studied by them. It was concluded that analogic design method is an effective category to be used, both analogy by sources inside architecture field and outside. Both analogy of form, meaning, and image. In addition, the level of diversity and depth understanding of design methods also influence the success of architectural design by themes.
\end{abstract}

Keywords: design method, theme, image, meaning

\section{PENDAHULUAN}

Bentuk pembelajaran studio dalam bidang arsitektur menuntut keterlibatan seluruh pelaku, dosen maupun mahasiswa, untuk membentuk jaringan yang dinamis dan terpadu (Arifin \& Kiswandono, 2002). Studio didefinisikan sebagai pembelajaran untuk menekuni ragam dan kombinasi filsafat, ilmu pengetahuan dan teknologi, termasuk seni, dengan mensimulasikan permasalahan nyata agar dapat ditemukan, dianalisis, dan menghasilkan sintesis sebagai alternatif solusi, serta dievaluasi, secara sistematis dan tematis.

Dalam pendidikan arsitektur, pembelajaran studio secara lazim digunakan untuk melatih keterampilan mahasiswa memproses perancangan arsitektur secara komprehensif. Pembelajaran studio memberikan kesempatan bagi mahasiswa untuk mengekplorasi perancangan arsitektur sekaligus membuktikan dan atau menerapkan teori-teori berkaitan yang dipelajari. Metode pembelajaran eksploratif 
lebih efektif meningkatkan pemahaman dan memperluas wawasan mahasiswa (Purwantiasning, 2014).

Tema menjadi salah satu pendekatan dalam perancangan arsitektur yang mampu membantu mahasiswa menghasilkan karya yang unik (Nurdiani, 2012). Tema melibatkan subyek untuk menjadikannya sebagai titik awal untuk melakukan bahasan, ulasan, dan tindakan intelektual. Secara singkat, tema melandasi semua olahan, tindakan intelektual, atau seni dalam berkarya. Dengan demikian, merancang arsitektur dengan tema berarti mengusulkan kemungkinan perwujudan rancangan dengan pertanggungjawaban dari gagasan berlandaskan pada tema tersebut, terutama mulai pada tahap pemrograman konsep sampai dengan perancangan gambar.

Perbedaan proses perancangan yang menggandeng tema dengan yang tidak adalah kebutuhan akan metode pencarian gagasan untuk mengeksplorasi konsep untuk mengimplementasikan tema. Konsep yang dihasilkan harus mampu men"citra"kan maksud dari tema rancang, dengan kata lain "makna". Citra merupakan suatu gambaran, memberikan kesan yang membuat seseorang mampu menangkap arti/makna di dalamnya (Warnata, 2017). Dalam arsitektur, citra merujuk pada tingkat kebudayaan, tidak hanya guna. Oleh karena itu, mahasiswa studio perancangan ini diharuskan mempelajari beberapa teori rancang yang sesuai sehingga dapat menemukan pedoman atau metode ekplorasi konsep perancangan tematik di dalamnya.

Kelemahan yang ditemukan dalam pembelajaran studio perancangan arsitektur tematik strata satu di Universitas Merdeka Surabaya, dimana penulis bekerja, adalah kualitas lulusan mata kuliah tersebut yang cenderung kurang mencitrakan tema, bahkan terjadi penurunan. Hal ini terlihat dari penurunan nilai rata-rata seluruh mahasiswa studio perancangan mencapai $5-7 \%$ setiap periodenya.

Dalam Penelitian Tindakan Kelas (PTK) studio sebelumnya (Rijal \& Aldy, 2012), ditemukan bahwa korelasi penyelesaian studio mahasiswa dengan input kuliah dalam studio lebih besar $(0,808)$ dibandingkan korelasi dengan input dari mata kuliah lain $(0,778)$. Input pengetahuan ini merupakan faktor yang signifikan mempengaruhi keberhasilan mahasiswa dalam sistem penyelenggaraan studio. Pengetahuan akan metode eksplorasi konsep mahasiswa di Universitas Merdeka Surabaya diperoleh dari mata kuliah lain, antara lain: Metode Perancangan dan Teori Arsitektur, serta dari dalam Studio Perancangan Arsitektur VI juga yang mempelajari metode yang relevan untuk tujuan studio yang bersangkutan, yakni merancang arsitektur tematik.

Berdasarkan latar belakang tersebut, diduga bahwa pengefektifan pembelajaran mahasiswa tentang metode perancangan yang relevan akan dapat meningkatkan keberhasilan mahasiswa dalam studio. Oleh karena itu, dilakukan penelitian terhadap tiga periode studio berturut-turut tentang metode eksplorasi gagasan yang didayagunakan oleh mahasiswa untuk merancang pada tahap mengkreasikan konsep dalam perancangan arsitektur tematik. Tujuannya adalah untuk menemukan metode yang paling efektif didayagunakan oleh mahasiswa sehingga dapat menjadi pedoman untuk meningkatkan keberhasilan studio perancangan ini di kemudian hari, dengan sistem penyelenggaraan studio yang tepat dan efisien. Penelitian diuji melalui teori dan metode eksplorasi konsep tematik yang dipelajari oleh peserta studio setiap periode dengan teori dan metode yang berbeda selama dua tahun, serta gabungannya pada tahun ketiga, serta dikontrol dengan tema umum yang sama: "lokalitas surabaya".

\section{METODE}

Berdasarkan tujuannya, penelitian ini berusaha mendeskripsikan proses dan hasil rancangan mahasiswa untuk membuat peringkat metode perancangan apa yang paling mudah diterapkan oleh mahasiswa untuk menyampaikan makna melalui pencitraan rancangan bangunan tematik yang dibuat. Metode kualitatif dipilih karena penelitian ini dianggap sesuai dengan karakteristik penelitian kualitatif (Groat \& Wang, 2013), yaitu: 
- Mengutamakan kondisi ilmiah secara natural: mahasiswa, dosen, dan studio diamati oleh peneliti dalam keadaan kegiatan pembelajaran yang natural, tanpa mengetahui bahwa studio dalam sedang diteliti;

- Berfokus pada interpretasi dan makna: peneliti sangat berperan dalam menilai dan menetapkan tingkat keberhasilan hasil rancangan setiap mahasiswa karena tidak hanya jenis metode apa yang paling banyak dipakai oleh mahasiswa dalam merancang, melainkan dipertimbangkan pula keberhasilan rancangan dengan mendayagunakan metode-metode tersebut;

- Berfokus pada bagaimana responden dapat memahami keadaan mereka sendiri: dimana mahasiswa sebagai responden diamati dan diarahkan sehingga mereka mengetahui situasi kegiatan perancangan mereka, berkaitan dengan tema dan metode yang digunakan, sehingga dapat menghasilkan rancangan yang optimal;

- Menggunakan multi-taktik dalam penelitian: kegiatan pengumpulan dan analisa data dilakukan menggunakan berbagai taktik yang dianggap sesuai dan efektif. Sebagai contoh: hubungan antara metode ekplorasi konsep perancangan tematik yang dipakai dengan kualitas rancangan tidak selalu berbanding lurus. Untuk memperoleh hasil keduanya, digunakan taktik kuantitatif dan kualitatif;

- Penalaran induktif yang signifikan: bahwa ketiga siklus penelitian ini (tiga tahun akademik), meskipun merupakan perulangan, namun di dalamnya dapat terjadi perkembangan yang tidak terduga selama proses penelitian. Hal ini dapat terjadi karena mahasiswa (responden) yang berbeda tiap periode, bahkan permasalahan dalam perancangan setiap mahasiswa pun berbeda meskipun dalam satu periode yang sama.

Fokus penelitian ini adalah melakukan analisis secara kualitatif terhadap tiga kelompok studi kasus. Tiga kelompok yang menjadi subyek penelitian adalah seluruh mahasiswa Studio Perancangan Arsitektur VI pada Program Studi Arsitektur, Fakultas Teknik, Universitas Merdeka Surabaya periode:
Tabel 1. Subyek Penelitian

\begin{tabular}{|c|c|l|c|}
\hline No. & $\begin{array}{c}\text { Tahun } \\
\text { Akademik }\end{array}$ & \multicolumn{1}{|c|}{ Judul Tugas } & $\begin{array}{c}\text { Jumlah } \\
\text { Mahasiswa }\end{array}$ \\
\hline 1. & $2016 / 2017$ & $\begin{array}{l}\text { Gedung } \\
\text { Pertunjukan/Teater } \\
\text { atau } \\
\text { Pameran/Galeri } \\
\text { atau Museum Seni } \\
\text { Surabaya }\end{array}$ & 13 \\
\hline 2. & $2017 / 2018$ & $\begin{array}{l}\text { Taman Budaya } \\
\text { Surabaya }\end{array}$ & 9 \\
\hline 3. & $2018 / 2019$ & $\begin{array}{l}\text { Pusat Olahraga } \\
\text { Surabaya }\end{array}$ & 11 \\
\hline
\end{tabular}

Penentuan subyek penelitian ini berdasarkan pada kemudahan dan kedalaman pengamatan karena merupakan mata kuliah yang diampu oleh penulis.

Beberapa taktik pengumpulan data yang dapat digunakan pada penelitian kualitatif adalah wawancara, focus group, survei, observasi, dan arsip (Groat \& Wang, 2013). Taktik yang digunakan harus mampu mengumpulkan data untuk menggambarkan variabel-variabel penelitian yang telah ditentukan. Oleh karena itu, taktik yang paling efektif adalah penggabungan antara observasi dan arsip.Variabel ditentukan secara jelas untuk memudahkan pengukuran dan pendeskripsian obyek penelitian, antara lain:

1. Kualitas Rancangan: bahwa perlu dideskripsikan kualitas rancangan yang berkaitan dengan bagaimana keberhasilan mahasiswa dalam mendayagunakan metode ekplorasi konsep perancangan tematik. Rancangan dianggap berhasil jika mampu mencitrakan makna yang ingin disampaikan. Data diperoleh melalui penilaian arsip laporan tugas-tugas mahasiswa untuk menilai hasil akhir rancangan dan observasi (pengamatan) kemajuan pekerjaan mahasiswa melalui asistensi/konsultasi untuk menilai keotentikan tugas;

2. Metode Perancangan: bahwa jenis metode ekplorasi konsep perancangan tematik apa yang paling digemari mahasiswa. Hal ini dapat diukur melalui perhitungan jumlah mahasiswa yang menggunakan setiap jenis metode perancangan. Jenis-jenis metode ekplorasi konsep perancangan tematik dijelaskan kepada mahasiswa pada awal perkuliahan. Data diperoleh melalui 
pengkajian arsip laporan tugas "konsep" dan "pengembangan rancangan";

3. Tema Rancangan: bahwa tema rancangan perlu ditentukan untuk mengendalikan penelitian sebagai variabel kontrol sehingga memudahkan peneliti untuk mengukur proses perancangan dan kualitas rancangan secara setara. Tema rancangan yang dipakai untuk ketiga kelompok adalah dalam koridor "Lokalitas Surabaya".

Penelitian dilakukan di Studio Perancangan Arsitektur, Fakultas Teknik, Universitas Merdeka Surabaya selama perkuliahan masing-masing periode semester tahun akademik terkait. Metode ekplorasi konsep perancangan tematik untuk menyampaikan citra-makna dalam bangunan dipelajari pada mata kuliah pada semester sebelumnya (Teori Arsitektur), dimana mahasiswa diarahkan mempelajari metode setiap periode, yakni:

- Tahun 2016/2017 mempelajari teori “Types of Design" (Broadbent, Bunt, \& Jencks, 1980);

- Tahun 2017/2018 mempelajari teori "Creativity Channels" (Antoniades, 1990); serta

- Tahun $2018 / 2019$ mempelajari kedua teori di atas.

Metode analisis yang digunakan adalah deskriptif, yakni pencarian fakta dengan interpretasi yang tepat untuk menggambarkan objek yang diteliti sesuai fenomena secara natural. Proses pengolahan data dalam penelitian kualitatif hingga dilakukan interpretasi dilakukan dalam beberapa tahap (Groat \& Wang, 2013). Hubungan di antaranya dideskripsikan sebagai hubungan interaktif, terutama hubungan antara pengumpulan data dan pemampatan data karena dapat terjadi hubungan siklus interaktif maju-mundur. Penjabaran proses analisis data yang dimaksud adalah:

\section{Pengumpulan Data}

Data primer dalam penelitian ini adalah Laporan Tugas Studio Perancangan Arsitektur VI seluruh mahasiswa. Tugas dipisahkan secara bertahap ke dalam lima tugas. Kelima tugas ini lah yang menjadi data yang harus dianalisis untuk memperoleh informasi dan menyimpulkan hasil penelitian. Metode observasi terhadap mahasiswa juga dilakukan untuk mempelajari proses dan keotentikan rancangan setiap mahasiswa.

\section{Pemampatan Data}

Dari kelima laporan tugas setiap mahasiswa, perlu dilakukan pengurangan volume data ke dalam kumpulan-kumpulan data yang dapat diolah (manageable). Pemampatan data ini dilakukan dengan melakukan pengelompokan/penggolongan data berdasarkan variabel penelitian. Data tugas yang paling banyak bermanfaat adalah tugas tema dan konsep hingga pengembangan rancangan.

\section{Penampilan Data dan Analisis}

Penampilan data adalah kegiatan menyusun sekumpulan data sehingga memberikan informasi yang dibutuhkan untuk penarikan kesimpulan. Berikut ini adalah teknik penampilan data yang digunakan:

- Foto, gambar, dan sketsa, untuk menampilkan hasil-hasil rancangan mahasiswa;

- Deskripsi atau teks naratif, digunakan untuk sebagai pendukung penampilan data yang membutuhkan penjelasan lebih rinci;

- Kajian Literatur sangat dibutuhkan untuk mengkaji landasan menilai keberhasilan metode perancangan dalam studio dimana harus dapat dipertanggungjawabkan secara teoritis.

- Interaction matrix (Jones, 1970), untuk menampilkan hubungan dan perbandingan antara metode perancangan dalam "Creativity Channels" dan "Types of Design" karena kedua kelompok metode tersebut lah yang disampaikan kepada mahasiswa Studio Perancangan Arsitektur VI;

- Untuk memperoleh simpulan-simpulan sementara, digunakan metode Ranking and Weighting (Jones, 1970) sehingga diperoleh metode yang paling efektif digunakan mahasiswa. Pembobotan digunakan untuk pengukuran Variabel Kualitas Rancangan dengan menggunakan skala 0-4 dengan rincian:

0 . tidak menyelesaikan rancangan,

1. tidak berhasil mengimplementasikan tema, 
2. kurang dari 3 konsep yang mengimplementasikan tema dan kurang mengakomodasi komponen arsitektur lainnya,

3. kurang dari 3 konsep mengimplementasikan tema namun telah mengakomodasi komponen arsitektur lainnya dengan baik,

4. lebih dari 3 konsep mengimplementasi tema dan telah mengakomodasi komponen arsitektur lainnya dengan baik;

\section{Penggambaran Kesimpulan}

Interpretasi hasil penelitian dilakukan secara terus-menerus selama proses penelitian bertujuan untuk menghasilkan kesimpulan-kesimpulan sementara yang masih bersifat longgar dan terbuka, sampai dengan dapat ditarik kesimpulan akhir yang lebih rinci.

\section{HASIL DAN PEMBAHASAN}

Ada dua macam teori rancang yang diajarkan secara singkat pada awal penugasan tentang tema dan metodenya (Tugas IV), yaitu:

A. Types of Design (Broadbent et al., 1980), terdiri dari:

1. Pragmatic,

2. Typologic,

3. Analogic:
a. Visual,
b. Structural,
c. Philoshopical;

4. Canonic;

B. Creativity Channels (Antoniades, 1990), terdiri dari:

1. Tangible Channels:

a. History, Historicism, and Study of Precedent,

b. Mimesis,

c. Geometry,

d. Focus on Materials;

2. Intangible Channels:
a. Metaphor,
b. Paradox
c. Transformation,
d. Obscure.

Tidak keseluruhan metode dalam kedua buku tersebut diajarkan dengan pertimbangan: materi tersebut telah diperoleh pada mata kuliah Teori Arsitektur, tidak semua metode dapat dikaitkan dengan perancangan tematik.

Langkah awal yang dilakukan adalah menampilkan data, yakni tema, jenis metode yang dipakai, dan tingkat keberhasilan masingmasing mahasiswa yang dituangkan dalam pembobotan nilai antara 0-4. Penilaian dilakukan oleh peneliti sekaligus sebagai pengajar, khususnya menilai tahap perumusan konsep sampai dengan diperoleh hasil akhir rancangan. Berikut adalah tabel untuk menginformasikan data tersebut:

Tabel 2. Metode yang Dipakai dan Tingkat Keberhasilan Mahasiswa

\begin{tabular}{|c|c|c|c|}
\hline $\begin{array}{c}\text { Nama } \\
\text { Mahasiswa }\end{array}$ & $\begin{array}{c}\text { Tema } \\
\text { Rancang }\end{array}$ & $\begin{array}{l}\text { Metode yang } \\
\text { Dipakai }\end{array}$ & $\begin{array}{c}\text { Tingkat } \\
\text { Ke- } \\
\text { berhasil } \\
\text {-an } \\
\end{array}$ \\
\hline \multicolumn{4}{|c|}{ Tahun Akademik 2016/2017 } \\
\hline $\begin{array}{l}\text { Dedy } \\
\text { Andris }\end{array}$ & Keberanian & $\begin{array}{l}\text { Philosophical + } \\
\text { Visual Analogic }\end{array}$ & 2 \\
\hline Rohmat Tri & Semanggi & Visual Analogic & 3 \\
\hline $\begin{array}{l}\text { Rulam } \\
\text { Angga }\end{array}$ & Perjuangan & $\begin{array}{l}\text { Philosophical + } \\
\text { Visual Analogic }\end{array}$ & 2 \\
\hline Abdul Azis & - & - & 0 \\
\hline $\begin{array}{l}\text { Akhmad } \\
\text { Hadi }\end{array}$ & $\begin{array}{c}\text { Perjalanan } \\
\text { Kesenian } \\
\text { Ludruk } \\
\end{array}$ & $\begin{array}{l}\text { Philosophical }+ \\
\text { Visual Analogic }\end{array}$ & 3 \\
\hline $\begin{array}{l}\text { Agung } \\
\text { Wahyu }\end{array}$ & $\begin{array}{c}\text { Tari } \\
\text { Remong }\end{array}$ & Visual Analogic & 1 \\
\hline Sindu Adi & Gambang & Visual Analogic & 2 \\
\hline $\begin{array}{l}\text { Paul } \\
\text { Matuan } \\
\end{array}$ & Rumah Adat & Typologic & 1 \\
\hline Yuli & Trinetra & $\begin{array}{l}\text { Philosophical + } \\
\text { Visual Analogic }\end{array}$ & 3 \\
\hline $\begin{array}{l}\text { Irfan } \\
\text { Susanto }\end{array}$ & $\begin{array}{l}\text { Monumen } \\
\text { Tugu } \\
\text { Pahlawan } \\
\end{array}$ & Typologic & 3 \\
\hline Shon Hadi & Remong & Visual Analogic & 4 \\
\hline $\begin{array}{l}\text { Hendra } \\
\text { Setiawan }\end{array}$ & Sate Kol & Visual Analogic & 2 \\
\hline M. Fendy & $\begin{array}{c}\text { Zoomorphic } \\
\text { Surabaya }\end{array}$ & Visual Analogic & 3 \\
\hline \multicolumn{3}{|c|}{ Rata-rata tingkat keberhasilan } & 2,42 \\
\hline
\end{tabular}




\begin{tabular}{|c|c|c|c|}
\hline \multicolumn{4}{|c|}{ Tahun Akademik 2017/2018 } \\
\hline Abu Dawud & $\begin{array}{l}\text { Lontong } \\
\text { Balap }\end{array}$ & $\begin{array}{l}\text { Tangible } \\
\text { Metaphor }\end{array}$ & 2 \\
\hline $\begin{array}{l}\text { Taufik } \\
\text { Huda }\end{array}$ & Cak \& Ning & $\begin{array}{c}\text { Intangible } \\
\text { Metaphor }+ \\
\text { Transformation } \\
\text { Borrowing }\end{array}$ & 2 \\
\hline Fafa Arifa'i & $\begin{array}{c}\text { Kepahlawan } \\
\text { an }\end{array}$ & $\begin{array}{l}\text { Combined } \\
\text { Metaphor }\end{array}$ & 1 \\
\hline $\begin{array}{l}\text { Badai } \\
\text { Virdhyliaw } \\
\text { an }\end{array}$ & $\begin{array}{l}\text { Wayang } \\
\text { Klitik }\end{array}$ & $\begin{array}{l}\text { Transformation } \\
\text { Borrowing }\end{array}$ & 1 \\
\hline Noviyanti & $\begin{array}{l}\text { Rujak } \\
\text { Cingur }\end{array}$ & $\begin{array}{l}\text { Tangible } \\
\text { Metaphor }\end{array}$ & 3 \\
\hline Rina Wati & Semanggi & $\begin{array}{l}\text { Tangible } \\
\text { Metaphor }\end{array}$ & 3 \\
\hline Tri Lestari & $\begin{array}{l}\text { Gunungan } \\
\text { Wayang }\end{array}$ & $\begin{array}{l}\text { Transformation } \\
\text { Borrowing }\end{array}$ & 4 \\
\hline Yohan Edi & $\begin{array}{l}\text { Pertikaian } \\
\text { Sarip } \\
\text { Tambak } \\
\text { Oso }\end{array}$ & $\begin{array}{c}\text { Tangible } \\
\text { Metaphor }+ \\
\text { Transformation } \\
\text { Borrowing }\end{array}$ & 2 \\
\hline Abdul Azis & - & - & 0 \\
\hline \multicolumn{3}{|c|}{ Rata-rata tingkat keberhasilan } & 2,25 \\
\hline \multicolumn{4}{|c|}{ Tahun Akademik 2018/2019 } \\
\hline $\begin{array}{l}\text { Didik } \\
\text { Irnawan }\end{array}$ & Bakau & Visual Analogic & 2 \\
\hline Fathur Rozi & - & - & 0 \\
\hline $\begin{array}{l}\text { M. } \\
\text { Saifuddin }\end{array}$ & $\begin{array}{l}\text { Surabaya } \\
\text { Membara }\end{array}$ & $\begin{array}{l}\text { Philosophical }+ \\
\text { Visual Analogic }\end{array}$ & 2 \\
\hline $\begin{array}{l}\text { Yosua } \\
\text { Novy }\end{array}$ & $\begin{array}{l}\text { Sparkling } \\
\text { Surabaya }\end{array}$ & $\begin{array}{l}\text { Philosophical + } \\
\text { Visual Analogic }\end{array}$ & 1 \\
\hline Elok Nur & Enercharge & $\begin{array}{l}\text { Philosophical + } \\
\text { Visual Analogic }\end{array}$ & 1 \\
\hline $\begin{array}{l}\text { Yogi } \\
\text { Aditya }\end{array}$ & $\begin{array}{l}\text { Monumen } \\
\text { Furutistik } \\
\text { Surabaya }\end{array}$ & $\begin{array}{c}\text { History/ } \\
\text { historicism }\end{array}$ & 4 \\
\hline Fiki Rizaldi & - & - & 0 \\
\hline $\begin{array}{l}\text { Defi } \\
\text { Samudra }\end{array}$ & $\begin{array}{l}\text { Kesejarahan } \\
\text { Surabaya }\end{array}$ & $\begin{array}{c}\text { History/ } \\
\text { historicism }\end{array}$ & 1 \\
\hline Idul & Jengki & Typologic & 3 \\
\hline Supriyadi & Pantai & - & 0 \\
\hline $\begin{array}{l}\text { Yulitzar } \\
\text { Helmureldi }\end{array}$ & $\begin{array}{l}\text { Kota Tua } \\
\text { Surabaya }\end{array}$ & Typologic & 3 \\
\hline \multicolumn{3}{|c|}{ Rata-rata tingkat keberhasilan } & 2,13 \\
\hline
\end{tabular}

Tabel di atas memberikan informasi tentang metode yang digunakan mahasiswa dan tingkat keberhasilannya. Tingkat keberhasilan " 0 " dan atau penggunaan metode "-“ berarti mahasiswa tersebut tidak dapat menyelesaikan kegiatan studio. Tingkat keberhasilan tinggi berarti mahasiswa dapat mengimplementasikan tema ke dalam rancangan tanpa mengurangi keoptimalan fungsi arsitektur lainnya dalam rancangan. Rata-rata tingkat keberhasilan tidak memperhitungkan mahasiswa yang tidak dapat menyelesaikan studio.

Sebuah rancangan visual analogic yang dinilai cukup berhasil adalah Teater Surabaya bertema Remong yang dirancang oleh Shon Hadi. Yang menjadi sumber analogi adalah gamelan dan selendang yang menjadi ciri khas kesenian Tari Remong di Surabaya sehingga rancangan diwarnai dengan bidang-bidang melingkar dan bentuk luwes bak selendang yang sedang diayun-ayunkan. Nilai tambah diberikan kepada mahasiswa ini karena mampu secara konsisten mengimplementasikan sumber-sumber analoginya di sebagian besar wilayan perancangannya, termasuk ruang luar.

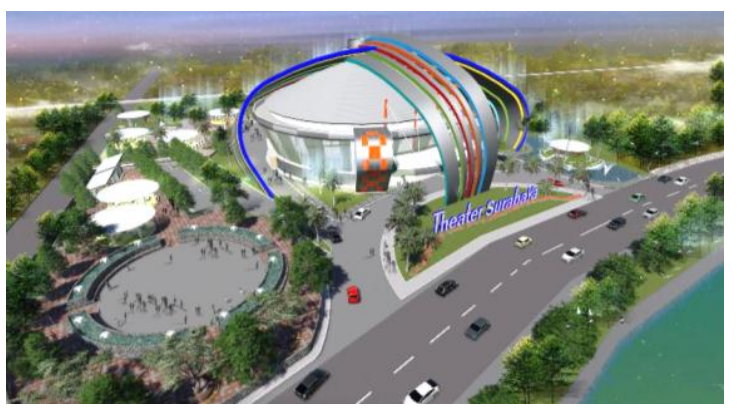

Gambar 1. Rancangan Teater Surabaya Bertema "Remong"

Sumber: Shon Hadi, 2017

Karya philosophical analogy yang cukup berhasil juga berasal dari periode studio yang sama, yaitu Museum Ludruk Surabaya bertema "Perjalanan Kesenian Ludruk" oleh Akhmad Hadi. Beranjak dari tema yang abstrak, perancang mencoba mewujudkannya melalui konsep sirkulasi pengunjung museum yang berkelanjutan, bahkan hingga menyamarkan sirkulasi vertikal dan horisontal, sesuai dengan perkembangan kesenian ludruk di Surabaya yang berkelanjutan hingga saat ini. Periodisasi Kesenian Ludruk dipilah ke dalam empat tingkat lantai museum, sesuai 
dengan empat periodisasi Kesenian Ludruk di Surabaya. Untuk meningkatkan kesan Ludruk dalam rancangan, dimanfaatkan pula visual analogy atas "udeng" yang merupakan salah satu perlengkapan busana yang terkenal di Surabaya, yang tidak jarang digunakan dalam kesenian Ludruk.

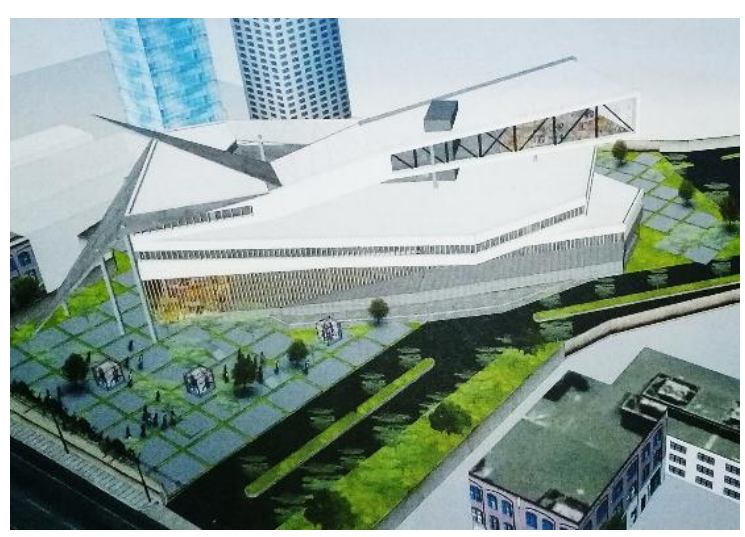

Gambar 2. Perspektif Rancangan Museum Ludruk Surabaya Bertema "Perjalanan Kesenian Ludruk" Sumber: Akhmad Hadi, 2017

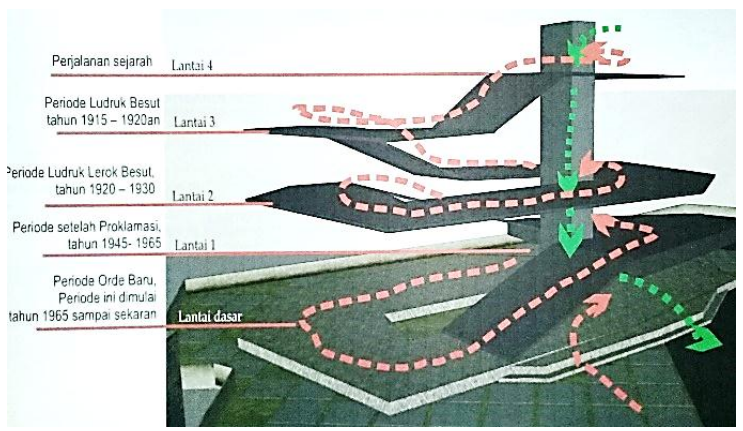

Gambar 3. Sketsa Konsep Sirkulasi dalam Bangunan

Sumber: Akhmad Hadi, 2017

Demikianlah latar belakang beberapa mahasiswa menggunakan metode analogi lebih dari satu, demi mempermudah interpretasi pengamat arsitektur terhadap makna yang ingin disampaikan melalui rancangannya. Hal ini sering dilakukan terhadap perancangan yang bertema abstrak karena dalam menginterpretasi tema tersebut, seringkali ditemukan beberapa komponen berwujud (rupa) yang selanjutnya diimplementasikan dalam rancangan.

Pada studio dengan proyek taman budaya, metode transformation borrowing menghasilkan sebuah rancangan yang komprehensif secara wujud atas tema
“Gunungan Wayang”, yakni karya Tri Lestari. Baik perancangan tapak, bangunan utama maupun pendukung, sampai dengan komponen ruang luar, termasuk gerbang, perteduhan, jalur sirkulasi, dan penataan taman, merupakan hasil implementasi dari tema.

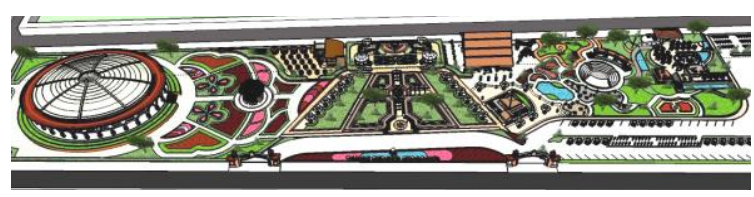

Gambar 4. Rancangan Taman Budaya Surabaya Bertema "Gunungan Wayang" Sumber: Tri Lestari, 2018

Selaras dengan makna Gunungan Wayang yang menyeluruh atas kehidupan manusia dan alamnya, pewujudan taman ini juga secara menyeluruh mencitrakan setiap bagian Gunungan Wayang, dengan kata lain berusaha mencitrakan makna-makna tersebut.

Salah satu karya mahasiswa yang dinilai berhasil menggunakan metode history/ historicism adalah Sport Center bertema Monumen Futuristik Surabaya oleh Yogi Aditya. Ia berusaha mengadopsi esensi bentuk beberapa monumen-monumen yang menjadi ikon Kota Surabaya, yaitu: Monumen Tugu Pahlawan, Sepuluh Nopember, dan Bambu Runcing, serta Taman Pelangi. Bentuk utama yang menonjol adalah bentuk runcing yang hampir selalu menjadi ciri monumen di Surabaya yang diinterpretasi olehnya berkaitan dengan keberanian, pengorbanan, semangat, kemegahan, dan kepercayaan diri. Sedangkan irama perulangan garis-garis tegas diagonal merupakan adopsi dari irama Monumen Pelangi. Meskipun tema hanya diimplementasikan pada wujud, tata ruang dan komponen arsitektur lainnya tetap optimal sesuai kebutuhan. 


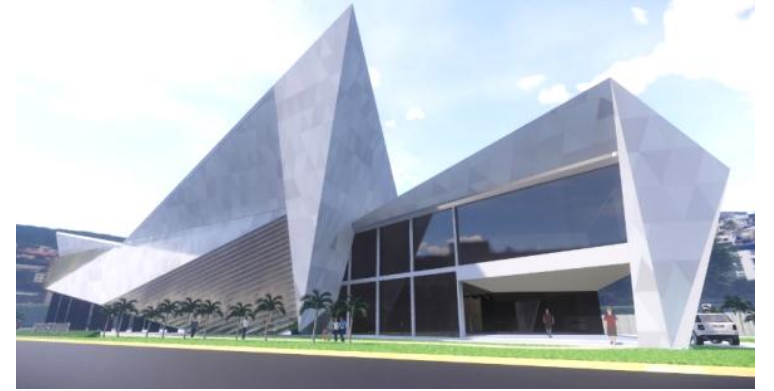

Gambar 5. Rancangan Sport Center Surabaya Bertema "Monumen Futuristik Surabaya" Sumber: Yogi Aditya, 2019

Sebuah metode yang meiliki tingkat kerumitan cukup tinggi dan jarang digunakan oleh mahasiswa adalah combined metaphor. Metode ini bukan menggunakan visual dan philosophical metaphor pada sumber analogi masing-masing yang berbeda, melainkan mengimplementasikan suatu analogi yang bersumber dari satu sumber, yang dianalogikan secara visual maupun filosofinya. Salah satu contoh karya mahasiswa adalah Taman Budaya Surabaya bertema "Kepahlawanan" oleh Fafa Arifa'i. Tema ini diinterpretasikan sebagai sesuatu yang abstrak, tentang perjuangan masyarakat Surabaya melawan penjajahan dari luar negeri. Perjuangan ini disimbolkan juga pada lambang Kota Surabaya, yaitu pertikaian atara "sura" (ikan hiu) dan "baya" (buaya).

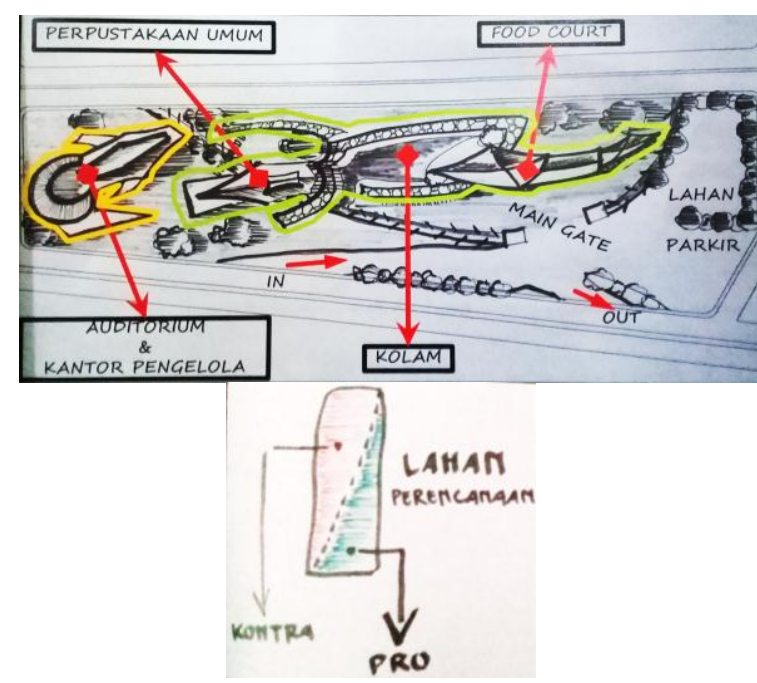

Gambar 6. Sketsa Konsep Tapak Taman Budaya Surabaya Bertema "Kepahlawanan" Sumber: Fafa Arifa'i, 2018
Tema tersebut diimplementasi dengan menekankan pada "pertikaian", ikan hiu, dan buaya. Tapak dibelah secara visual dengan luas yang tidak seimbang untuk menyampaikan "pertikaian" yang dimenangkan oleh salah satu pihak. Ikan hiu dianalogikan sebagai penjajah, sesuai makna lambang kota, diposisikan pada belahan kecil lahan, sebagai pihak yang kalah. Analogi buaya, di belahan tapak lainnya. Ikan hiu sebagai gedung auditorium yang menjadi sasaran utama perjuangan masyarakat surabaya, dirancang sebagai sasaran utama pengunjung taman. Namun sayang, perancangan ini kurang berhasil karena terlalu lama mengalokasikan waktu untuk perumusan konsep sehingga banyak komponen arsitektur lain yang kurang dioptimasi.

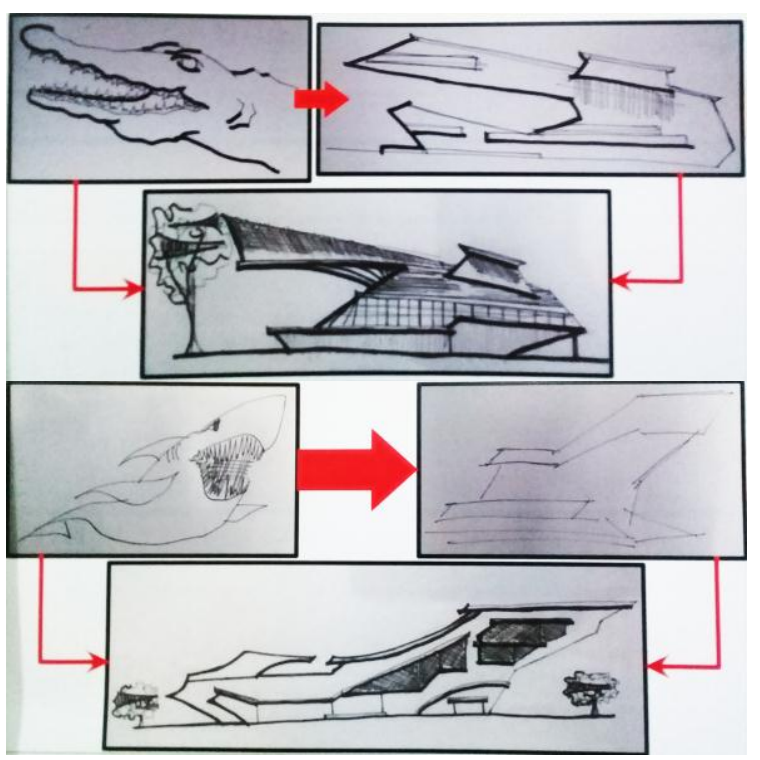

Gambar 7. Sketsa Konsep Bangunan Taman Budaya Surabaya Bertema "Kepahlawanan" Sumber: Fafa Arifa'i, 2018

Langkah selanjutnya adalah menyetarakan metode-metode dari dari dua teori yang berbeda sehingga semua periode studio dapat dibandingkan secara setara. Sebagai awalan, untuk menyetarakan metode antara teori Types of Design dan Creativity Channels, dibuat matrik sederhana hubungan antara kedua teori tersebut, di bawah ini. Dalam matrik tersebut, metode yang ditandai dengan garis diagonal adalah metode yang digunakan oleh mahasiswa dalam tiga periode Studio Perancangan Arsitektur VI. 
Matrik sederhana di bawah ini dapat memberikan informasi kecenderungan mahasiswa lebih tertarik menggunakan metode untuk perancangan tematik yang bersifat abstrak tetapi masih sejalan dengan kesepakatan bersama, serta lebih bersifat teraga secara fisik, bukan yang memerlukan interpretasi yang dalam untuk menemukan makna sebuah rancangan, meskipun minoritas mahasiswa juga melakukan itu. Namun demikian, kesemuanya masih berada dalam menganalogikan rancangan dengan benda lain atau tipologi bentuk arsitektur terdahulunya.

Tabel 3. Hubungan Metode Rancang Teori "Types of Design" dan "Creativity Channels"

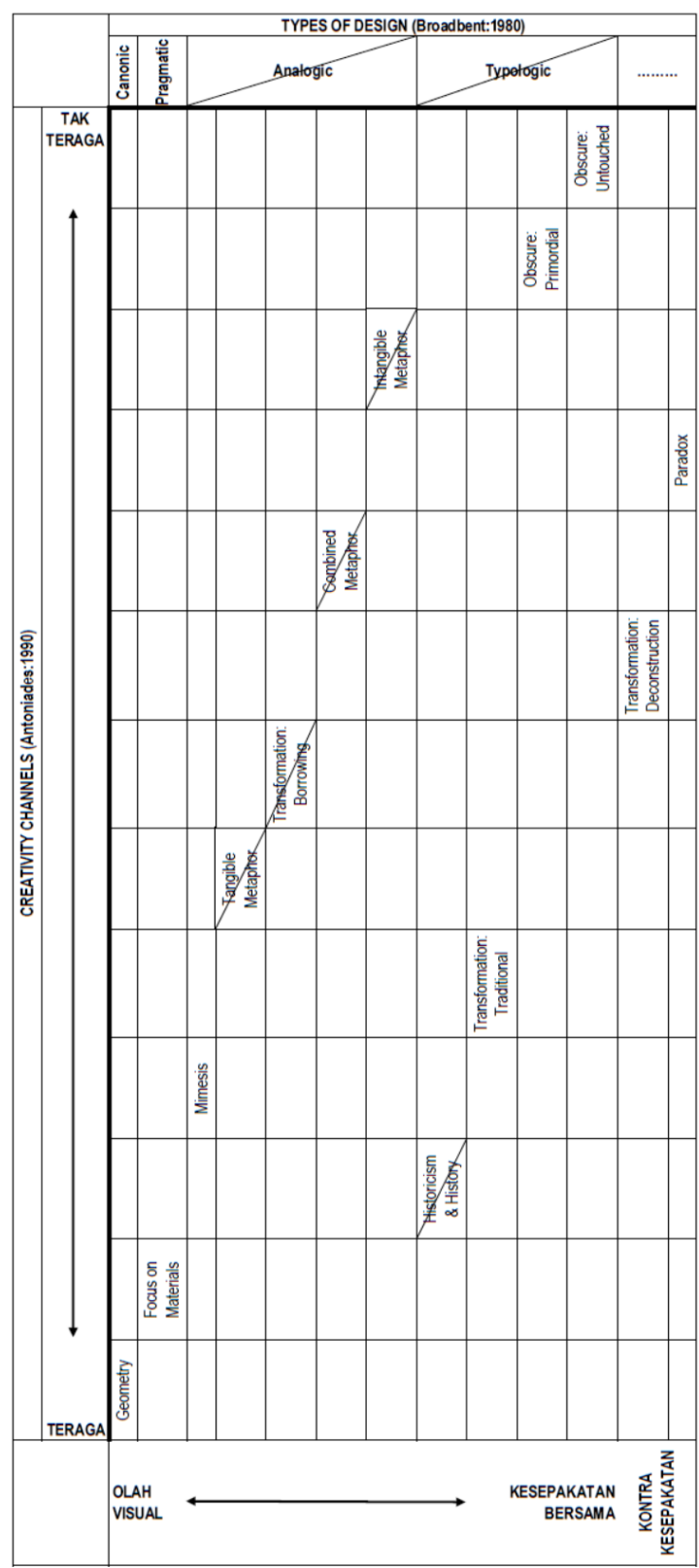

Dalam pandangan metode rancang secara umum, sesuai dengan teori "design methods" (Jones, 1970), metode-metode yang digunakan mahasiswa tersebut di atas termasuk dalam kategori "methods of searching for ideas", dengan kata lain, menghasilkan gagasan. Metode analogi terhadap benda lain termasuk dalam "synectics". Sedangkan olahan bentuk berdasarkan arsitektur terdahulunya, tidak dijelaskan Jones secara khusus dalam bukunya, namun dapat dikaitkan secara umum dengan metode "transformation" dalam "removing mental block".

Synectics merupakan pembelajaran proses kreatif, terutama diterapkan untuk solusi suatu masalah dengan kelompok yang terdiri dari individu yang berbeda. Strategi mempertemukan berbagai macam unsur, dengan menggunakan kiasan untuk memperoleh satu pandangan baru. Metode ini bertujuan untuk mengarahkan aktifitas spontan otak kepada eksplorasi dan transformasi permasalahan rancang dengan mendayagunakan kemampuan dari bidang lain, dalam kasus perancangan ini adalah bidang dari luar arsitektur.

Synectics ini dibedakan menjadi empat analogi (Jones, 1970), direct, personal, symbolic, dan fantasy analogy. Untuk dapat menggeneralisasi metode-metode analogi lintas teori yang dipelajari dan digunakan mahasiswa, dilakukan penyetaraan, khusus alanogi, yang lebih umum berdasarkan Synectics dalam Design Methods. Namun penyetaraan ini bukan mengartikan bahwa beberapa metode yang disandingkan adalah sama atau hampir, melainkan dapat termasuk atau merupakan "bagian dari". Berikut adalah tabel penyetaraan yang mungkin dapat dipahami antara analogi-analogi dalam sinektik dengan metode dalam Types of Design dan Creativity Channels yang digunakan mahasiswa: 
Tabel 4. Penyetaraan Metode Analogi dalam Teori "Types of Design" dan "Creativity Channels"

Berdasarkan "Design Methods” secara Umum.

\begin{tabular}{|l|l|l|}
\hline $\begin{array}{c}\text { Design } \\
\text { Methods } \\
\text { (Jones, } \\
\text { 1970) }\end{array}$ & $\begin{array}{c}\text { Types of } \\
\text { Design } \\
\text { (Broadbent et } \\
\text { al, 1980) }\end{array}$ & $\begin{array}{c}\text { Creativity } \\
\text { Channels } \\
\text { (Antoniades, 1990) }\end{array}$ \\
\hline $\begin{array}{l}\text { Direct } \\
\text { Analogy }\end{array}$ & $\begin{array}{l}\text { Philososphical } \\
\text { Analogy }\end{array}$ & $\begin{array}{l}\text { Intangible } \\
\text { Metaphor } \\
\text { Combined } \\
\text { Metaphor }\end{array}$ \\
\hline $\begin{array}{l}\text { Personal } \\
\text { Analogy }\end{array}$ & Structural & $\begin{array}{l}\text { Intangible } \\
\text { Analogy } \\
\text { Combined } \\
\text { Metaphor }\end{array}$ \\
\hline $\begin{array}{l}\text { Symbolic } \\
\text { Analogy }\end{array}$ & Visual & $\begin{array}{l}\text { Tangible Metaphor } \\
\text { Transformation } \\
\text { Borrowing }\end{array}$ \\
\hline $\begin{array}{l}\text { Fantasy } \\
\text { Analogy }\end{array}$ & - & - \\
\hline
\end{tabular}

Berdasarkan tabel di atas, dapat disimpulkan bahwa terdapat tiga jenis analogi yang digunakan. Direct analogy yang menggunakan istilah tertentu sebagai gagasan utama, namun implementasinya membutuhkan pemahaman secara mendalam atas istilah tersebut. Dengan kata lain, yang dianalogi adalah karakter, sifat non-fisik, atau "makna"-nya. Yang kedua adalah Symbolic Analogy yang membandingkan bentuk luar, tampilan, ciriciri fisik atau "wujud". Sedangkan yang ketiga adalah analogi yang menggabungkan keduanya. Analogi gabungan ini memiliki arti bahwa wujud dan makna yang diperbandingkan adalah berasal dari satu sumber analogi, saling berkaitan dan dianalogikan secara bersamaan, combined methapor. Produk dari penggabungan ini dapat disebut sebagai "citra", dimana wujud yang dihasilkan dapat menggambarkan makna yang ingin disampaikan, dalam kasus ini adalah tema rancangan masing-masing mahasiswa. Berbeda dengan analogi wujud yang tidak mempertimbangkan makna di baliknya, citra diwujudkan dalam kaitannya untuk mengesankan makna di baliknya pula.

Metode transformasi dalam "removing mental block" lebih ditekankan terhadap solusi rancang, bukan pada olahan bentuk saja. Namun jika dikaitkan, dapat dipahami bahwa cara yang digunakan oleh mahasiswa tersebut merupakan bagian dari metode transformasi karena dalam menganalogikan rancangan dengan bangunan lampau, dilakukan adaptasi, modifikasi, menata ulang, mengombinasi, dan sebagainya, yang kesemuanya termasuk dalam metode transformasi. Namun demikian, transformasi dalam kasus studio ini dibatasi pada transformasi hakekat, yakni perubahan bentuk atau wujud, yang berlandaskan pada preseden arsitektur. Pada dasarnya, langka sekali ditemukan pemanfaatan preseden tunggal sebagai olahan rancangan (Clark \& Pause, 2012). Sebaliknya, perancang umumnya menggabungkan berbagai preseden sehingga berpotensi menghasilkan kekayaan rancangan yang berlipat ganda. Transformasi wujud arsitektur sebaiknya dilakukan dengan mempelajari dahulu makna di balik wujud bangunan yang dijadikan preseden. Dengan mempelajarinya, citra yang dikonsepkan akan semakin dekat dengan makna di balik wujud arsitektur yang ingin dikinikan atau dimodernisasi (Paryoko, 2017).

Dengan ditetapkannya penyetaraan metode dari kedua teori rancang di atas, dilakukan analisis untuk mengetahui tingkat keberhasilan masing-masing metode dalam studio ini.

Tabel 5. Rata-rata Tingkat Keberhasilan Metode yang Digunakan Mahasiswa

\begin{tabular}{|l|c|c|}
\hline \multicolumn{1}{|c|}{ Metode } & $\begin{array}{c}\text { Jumlah } \\
\text { Penggunaan }\end{array}$ & $\begin{array}{c}\text { Rata-rata } \\
\text { Tingkat } \\
\text { Keberhasilan }\end{array}$ \\
\hline $\begin{array}{l}\text { Analogi } \\
\text { Wujud }\end{array}$ & 21 & 2,38 \\
\hline $\begin{array}{l}\text { Analogi } \\
\text { Makna }\end{array}$ & 8 & 2,00 \\
\hline Analogi Citra & 1 & 1,00 \\
\hline $\begin{array}{l}\text { Transformasi } \\
\text { Preseden }\end{array}$ & 6 & 2,50 \\
\hline
\end{tabular}

Meskipun terdapat tiga analogi yang berbeda seperti dijelaskan sebelumnya, terdapat perancang, dalam studio ini adalah mahasiswa, yang menggunakan lebih dari satu analogi, bukan analogi citra, melainkan menggunakan analogi wujud dan makna untuk sumber analogi yang berbeda untuk mengimplementasikan tema. Oleh karena itu, angka dalam "jumlah penggunaan" dapat melebihi jumlah peserta dalam ketiga periode studio. 
Penggunaan metode gabungan biasanya terjadi ketika tema yang ditetapkan bersifat abstrak karena dalam pengimplementasiannya harus melakukan intrepretasi sesuatu yang abstrak tersebut sehingga dapat diwujudkan/dirupakan. Berdasarkan observasi proses perancangan mahasiswa, ditemukan bahwa metode pengimplementasian tema dapat digunakan pada dua tahap yang berbeda dalam proses penyusunan konsep. Metode tersebut dapat digunakan langsung untuk mengkreasikan konsep untuk tema yang berwujud. Pada kasus tema yang abstrak, dapat muncul tahap interpretasi tema yang menghasilkan beberapa hasil interpretasi, baik yang berwujud maupun tidak. Pada saat pengkreasian hasil interpretasi ini lah, muncul potensi yang besar penggunaan lebih dari satu metode.

\section{KESIMPULAN}

Keberhasilan pembelajaran studio perancangan arsitektur tematik bergantung pada tahap eksplorasi gagasan untuk menghasilkan konsep yang mengimplementasikan tema, selain pertimbangan arsitektur lainnya yang telah dipelajari mahasiswa pada studio perancangan sebelumnya dan mata kuliah lain. Melalui penelitian ini diketahui metode yang paling efektif didayagunakan mahasiswa pada tahap eksplorasi gagasan tersebut untuk mengimplementasi tema. Namun, keragaman metode yang dipelajari diduga mempengaruhi tingkat pemahaman mahasiswa atas masingmasing metode sehingga terlalu beragamnya teori yang dipelajari tidak selalu berbanding lurus dengan keberhasilan rancangan. Hal ini dapat dilihat dari penurunan rata-rata tingkat keberhasilan mahasiswa dimana terjadi penambahan ragam metode yang dipelajari setiap periode dalam tiga tahun akademik.

Metode ekplorasi konsep rancangan arsitektur yang digemari mahasiswa cenderung adalah analogi yang tidak literal, melainkan bersifat lebih abstrak atau tidak teraga, namun tidak sampai dengan yang paradoksal atau melawan kesepakatan bersama dalam masyarakat umum. Baik analogi dengan sumber analogi berupa karya arsitektur maupun non-arsitektur. Metode yang paling efektif digunakan adalah:
1. Analogi Wujud,

2. Transformasi Preseden,

3. Analogi Makna, dan

4. Analogi Citra.

Urutan tersebut merupakan pemeringkatan metode berdasarkan frekuensi digunakan dan tingkat keberhasilannya. Wujud memang merupakan langkah tercepat bagi pengamat untuk "membaca" makna apa yang disampaikan arsitektur (Paryoko, 2017).

Untuk meningkatkan efektifitas bentuk pembelajaran studio perancangan arsitektur tematik selanjutnya, disarankan untuk lebih menggeneralisasikan metode ekplorasi konsep yang dipelajari mahasiswa. Penelitian selanjutnya diharapkan dapat mempelajari manajemen studio perancangan yang dapat menerapkan metode yang lebih beragam namun dengan tingkat keberhasilan yang tinggi, atau bahkan peserta studio mampu menghasilkan kerangka metode gabungan atau baru yang lebih efektif.

\section{REFERENSI}

Antoniades, A. C. (1990). Poetics of Architecture: Theory of Design. New York: Van Nostrand Reinhold.

Arifin, L. S., \& Kiswandono, I. (2002). Manajemen Pengajaran Di Studio Disain Arsitektur. DIMENSI (Jurnal Teknik Arsitektur), 30(1). Retrieved from http://puslit2.petra.ac.id/ejournal/index.p hp/ars/article/view/15761

Broadbent, G., Bunt, R., \& Jencks, C. (1980). Signs, symbols, and architecture. New York: John Wiley \& Sons.

Clark, R. H., \& Pause, M. (2012). Precedent in Architecture (Fourth Edi). New Jersey: John Wiley \& Sons.

Groat, L. N., \& Wang, D. (2013). Architectural Research Methods (Second). New Jersey: John Wiley \& Sons.

Jones, J. C. (1970). Design Methods. New York: John Wiley \& Sons.

Nurdiani, N. (2012). Evaluasi Proses Penelusuran Literatur dan Penerapan Topik-Tema dalam Perancangan Arsitektur. ComTech, 3(1), 15-22. 
Paryoko, V. G. P. J. (2017). Pencitraan Arsitektur Rumah Tradisional Pada Rumah Susun Di Kediri. Jurnal Arsitektur KOMPOSISI, 11(5), 179. https://doi.org/10.24002/jars.v11i5.1292

Purwantiasning, A. W. (2014). Eksplorasi Arsitektur Sebagai Salah Satu Metode dalam Proses Belajar Mengajar Mahasiswa Aktif di Jurusan Arsitektur Universitas Muhammadiyah Jakarta. JA!, 2, 40-47.

Rijal, M., \& Aldy, P. (2012). Implementasi Metode Studio-Based Learning dalam Pengelolaan dan Prosedur Pembelajaran Studio Perancangan Arsitektur. Journal of Education and Learning (EduLearn), 6(1), https://doi.org/10.11591/edulearn.v6i1.18 6

Warnata, I. N. (2017). Guna dan Citra Dalam Arsitektur. Undagi, 5(1), 1-8. 